(RESEARCH ARTICLE)

\title{
Heavy metals and anions content of treated and untreated waste water samples from Wupa sewage treatment plant Abuja
}

\author{
Chibueze Charles Okafor ${ }^{1}$ and Salaudeen Abdulwasiu Olawale ${ }^{2, *}$ \\ ${ }^{1}$ Chemistry Dept. University of Abuja, Nigeria. \\ ${ }^{2}$ Applied Mathematics Dept. (Chem. option) National Mathematical Centre, Abuja, Nigeria.
}

Publication history: Received on 09 April 2020; revised on 14 April 2020; accepted on 15 April 2020

Article DOI: https://doi.org/10.30574/wjarr.2020.6.1.0090

\begin{abstract}
Treated and untreated wastewater samples from Wupa Sewage Treatment Plant Idu Research and Industrial Layout Abuja were analyzed to determine the concentrations of $\mathrm{Cd}, \mathrm{Fe}, \mathrm{Cu}, \mathrm{Pb}, \mathrm{Zn}$ and anions like sulphate, chloride, nitrate and phosphate. Heavy metal analyses were performed by atomic absorption spectrophotometry. Mean heavy metal contents i.e. $\mathrm{Zn}, \mathrm{Cu}, \mathrm{Fe}, \mathrm{Cd}$ and $\mathrm{Pb}$ in water samples reduced from 0.13 to $0.05 \mathrm{mg} / \mathrm{l}, 0.05$ to $0.02 \mathrm{mg} / \mathrm{l}, 0.82$ to $0.22 \mathrm{mg} / \mathrm{l}, 0.001$ to $0.0002 \mathrm{mg} / \mathrm{l}$, and 0.001 to $0 \mathrm{mg} / \mathrm{l}$ respectively before and after treatment. There was decrease in phosphate, chloride and sulphate concentration after treatment with increase in nitrate and nitrate concentration after treatment, suggesting the plant might be inefficient in nitrate and nitrate treatment.
\end{abstract}

Keywords: Heavy metals; Anions; Wupa; Treatment plant; Chloride; Nitrate

\section{Introduction}

Safe discharge of untreated wastewater and scarcity of water is still a burning problem in front of mankind. Discharge of untreated wastewater, without any treatment affects the physicochemical properties of water and soil which enters into food chain and affects agriculture products, animal and human health. Studies of water quality in various effluents [1] revealed that anthropogenic activities have an important negative impact on water quality in the downstream sections of the major rivers. This is a result of cumulative effects from upstream development but also from inadequate wastewater treatment facilities [2]. Water quality decay, characterized by important modifications of chemical oxygen demand (COD), total suspended solids (TSSs), total nitrogen (TN), total phosphorous (TP), iron (Fe), nickel (Ni), copper $(\mathrm{Cu})$, zinc $(\mathrm{Zn})$, lead $(\mathrm{Pb})$, and so forth [3] are the result of wastewater discharge in rivers [2]. Water-related environmental quality has been shown to be far from adequate due to unknown characteristics of wastewater [4].

Water pollution plays a role in the occurrence of global 'water crisis', by reducing the quantity of freshwater resources available to man as well as the ecosystems. Shortage of freshwater is presently occurring in developing nations such as India, China and many African countries, as well as some developed countries [5]. Globally, 2.1 billion people are deprived of accessibility to clean water and about 4.5 billion have no access to adequate sanitation [6]. A recent UN report indicates that by 2025 , two-thirds of the population of the world could face water stress. The scarcity of water could be in the form of physical scarcity, where water availability is limited and demands are not met, or it could be in the form of economic scarcity, where although water is available, there are no means/ infrastructure to provide water of required quantity and quality [7].

The importance of wastewater analyses in order to identify the composition of the wastewater so actions can be taken to reduce the amount of trash discarded cannot be overemphasized [8]. The sewage water discharged from various domestic and industrial sources have been characterized by various researchers [9]. Urban environmental management is one of the important issues as the urbanization trend continues globally. The under management of municipal

\footnotetext{
* Corresponding author: Salaudeen Abdulwasiu Olawale
} 
wastewater in many southern urban areas is a major challenge. Management of wastewater in metropolitan cities is a very difficult task. The unsafe disposal of wastewater results in water pollution as well as terrestrial pollution. It causes various health problems that is epidemic due to the processing of the contaminated water [10]. These wastewater eutrophicates the water bodies, causing the mortality of aquatic biological resources. Hence, the role of treatment plants is in the sustainable use of wastewater as they make the water usable for various purposes [11].

This study is based on weekly measurements of chemical parameters of untreated and treated water samples from Wupa Sewage Treatment Plant Idu Research and Industrial Layout Abuja over a period of six weeks.

\section{Material and methods}

All reagents used for this research were of analytical grade unless otherwise stated. This research work was carried out over a period of six weeks.

\subsection{Sample Location}

Wupa Sewage Treatment Plant is located at Cadastral Zone Institute and Research District of Abuja FCT. The study area lies between latitude $7^{\circ} 20^{1}$ and $9^{\circ} 20^{1} \mathrm{~N}$ and longitude $6^{\circ} 45^{1}$ and $7^{\circ} 39^{1} \mathrm{E}$.

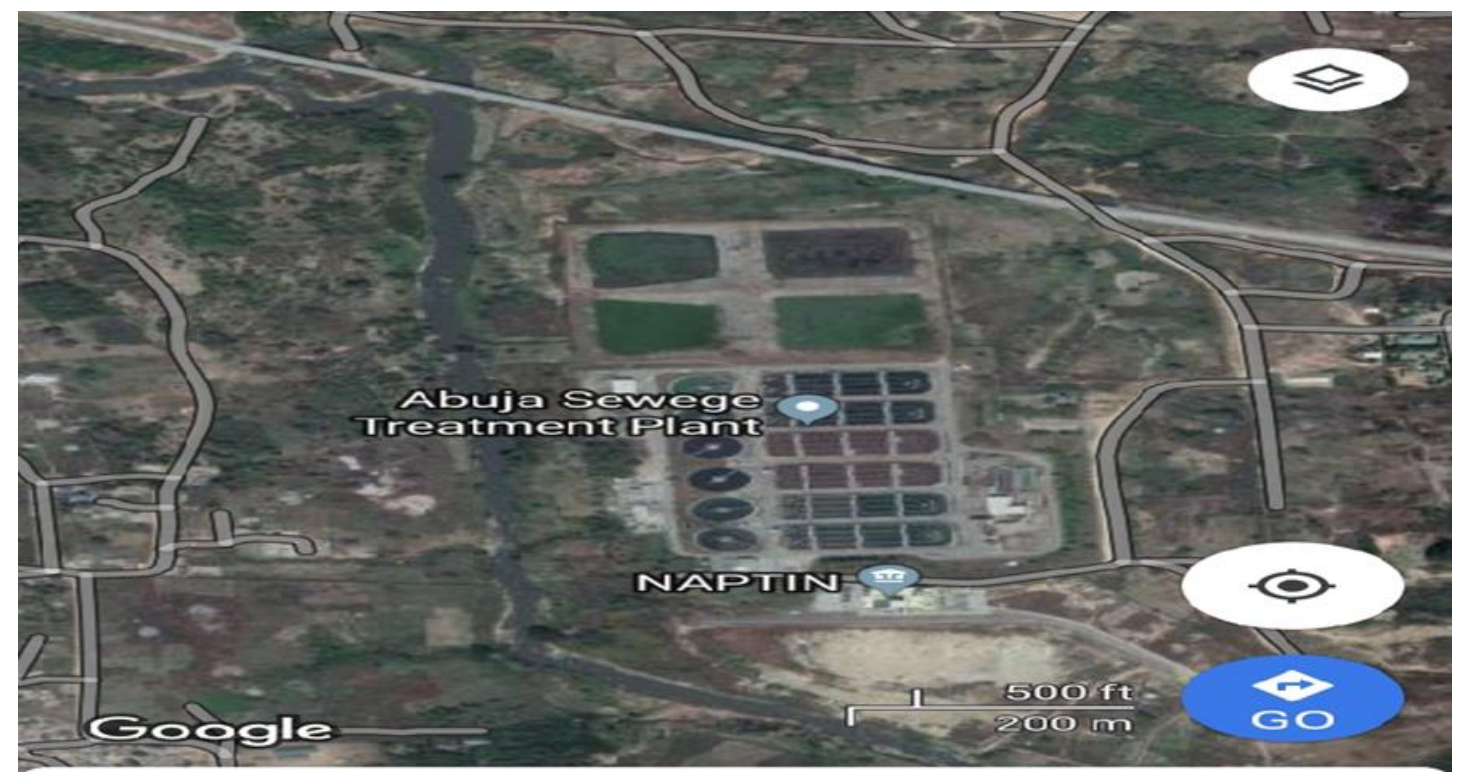

Figure 1 Google image of the treatment plant

\subsection{Methods of Analysis}

\subsubsection{Digestion}

$100 \mathrm{ml}$ of each wastewater sample was measured into a $250 \mathrm{ml}$ beaker and $10 \mathrm{ml}$ conc. $\mathrm{HNO}_{3}$ was added. This was evaporated to near dryness on hot plate at $90^{\circ} \mathrm{C}$ for 15 minutes. The beaker with the content was allowed to cool to room temperature after which another $10 \mathrm{ml}$ portion of conc. $\mathrm{HNO}_{3}$ and $5 \mathrm{ml} \mathrm{H}_{2} \mathrm{O}_{2}$ were added. The beaker was immediately covered with a watch glass and returned to the hot plate and the temperature increased to $105^{\circ} \mathrm{C}$. The heating was continued until a whitish residue was obtained. The residue was dissolved in $5 \mathrm{ml} \mathrm{conc.} \mathrm{HNO}_{3}$ and $5 \mathrm{ml}$ of distilled water was added. The solution was then filtered after cooling through Whatman paper No.42 into a $250 \mathrm{ml}$ volumetric flask and made to the mark with distilled water. The solution was transferred into polythene bottle prior to AAS analysis. Blank analysis was carried out. The digest was analysed for heavy metals using AAS ThermoScientificiCETM 3000 . Analysis of a mixture of metal standards ( $\mathrm{Pb}, \mathrm{Cu}, \mathrm{Cd}, \mathrm{Fe}$, and $\mathrm{Zn}$ ) prepared from their stock solutions were also carried out as part of the analytical data quality assurance. 


\subsection{Determination of nitrates}

Nitrate concentrations in wastewater samples were determined by the phenol disulphonic acid method. $50 \mathrm{ml}$ of the sample was pipetted into a $250 \mathrm{ml}$ beaker and evaporated to almost dryness on a hot plate. $0.5 \mathrm{ml}$ of phenol disulphonic acid was added, followed by carefully adding $10 \mathrm{ml}$ of $12 \mathrm{M} \mathrm{NaOH}$ to avoid spattering and the solution mixed by swirling. This was allowed to stand for 15 minutes with occasional swirling to ensure dissolution of solids and colour development. When cold, the mixture was diluted with nitrate free distilled water and the solution transferred into 50 $\mathrm{ml}$ volumetric flask and made to mark with distilled water. Standard solutions of nitrate (2-10 ml) were prepared and treated in similar way as the samples. The absorbance of the samples and standards were measured against that of the blank on a UV-visible spectrophotometer at $420 \mathrm{~nm}$. Calibration curve of absorbance against nitrate concentration was drawn from which nitrate concentrations in the sample were extrapolated.

\subsection{Determination of chloride}

Chloride ion in water samples was measured titrimetrically using the Mohr's method. This method employs silver nitrate as titrant and potassium chromate as the end-point indicator. Into $50 \mathrm{ml}$ of the neutralized sample was added 1 $\mathrm{ml}$ potassium chromate indicator and the sample titrated with $0.0282 \mathrm{M}$ silver nitrate solution to the reddish-brown colour end point. A blank titration of $50 \mathrm{ml}$ distilled water was also conducted.

\subsection{Determination of Nitrites}

The nitrite content in wastewater was determined by photometric method. The wastewater sample was placed in a volumetric flask of $100 \mathrm{ml}$ and filled to approximately $80 \mathrm{ml}$. Then $2 \mathrm{ml} \mathrm{Na}$-EDTA solution, $5 \mathrm{ml}$ sulfanilamide solution and $2 \mathrm{~mL}$ hydrochloric acid were added. After 3minutes $1 \mathrm{ml} \mathrm{N}$-(1-Naphtyl) ethylenediamine-dihydrochloride solution was also added. The graduation mark was filled up and mixed. The absorbance $\left(A_{x}\right)$ was determined after 15 minutes at $542 \mathrm{~nm}$ against water. The same was done for the blank determination of water (Absorbance $\mathrm{A}_{\mathrm{b}}$ ). A calibration graph of 5 solutions with known nitrite content was prepared from standard nitrite solution.

\subsection{Determination of sulphates}

Sulphates in the wastewater samples was determined by turbidimetric method. $100 \mathrm{ml}$ of the sample was measured into a $250 \mathrm{ml}$ Erlenmeyer flask and $5 \mathrm{ml}$ of conditioning reagent was added. While stirring on a magnetic stirrer, a spoonful of barium chloride crystals was added and stirred for another one minute at constant speed. Part of the solution was then poured into an absorption cell and the absorbance read at $425 \mathrm{~nm}$. Standard solution of sulphate (2$10 \mathrm{mg} / 1$ ) were prepared and treated the same way as samples. Sulphate concentrations were determined from the calibration curve prepared from the standards by plotting the Absorbance of the standard solution against the concentrations.

\subsection{Determination of phosphates}

Phosphate concentrations in wastewater samples were determined using the phosphate vanadomolybdate colorimetric method. $100 \mathrm{ml}$ of wastewater samples were measured into a $250 \mathrm{ml}$ Erlenmeyer flask and acidified with $\mathrm{conc} \mathrm{H}_{2} \mathrm{SO}_{4}$ to methyl orange (i.e. pH 3.3 to 4.0). The mixture boiled gently for 90 minutes to convert all forms of polyphosphate to orthophosphate. After cooling, excess acid was neutralized with $6 \mathrm{M} \mathrm{NaOH}$ until the appearance of faint pink colour of phenolphthalein. The solution was filtered through Whatman filter paper No.42 into a 100 ml volumetric flask and made to the mark with distilled water. $25 \mathrm{ml}$ sample were pipetted into $50 \mathrm{ml}$ volumetric flask and $10 \mathrm{ml}$ vanadate-molybdate reagents was added and the solution was diluted to the $50 \mathrm{ml}$ mark with distilled water. This was allowed to stand for 10 minutes for the colour to be fully developed. $25 \mathrm{ml}$ of phosphate standards solutions (0.5-2.5 ml) were prepared and treated as the samples. The absorbance of the samples and the standard were measured against that of the blank $(2.5$ $\mathrm{ml}$ distilled water) at $470 \mathrm{~nm}$, and phosphate concentrations in samples were determined from the calibration curve prepared with the standard phosphate solutions. 


\section{Results and discussion}

Table 1 Chemical characteristics of untreated water samples.

\begin{tabular}{|l|l|l|l|l|l|l|}
\hline Physicochemical Parameters & Week 1 & Week 2 & Week 3 & Week 4 & Week 5 & Week 6 \\
\hline Nitrate (mg/l) & 2.80 & 3.50 & 2.00 & 4.00 & 3.00 & 1.90 \\
\hline Nitrite (mg/l) & 0.11 & 0.17 & 0.09 & 0.11 & 0.17 & 0.10 \\
\hline Phosphate (mg/l) & 3.00 & 2.90 & 1.40 & 3.00 & 2.60 & 0.97 \\
\hline Chloride (mg/l) & 39.00 & 40.00 & 35.90 & 37.70 & 30.50 & 35.80 \\
\hline Sulphate (mg/l) & 46.90 & 37.80 & 39.50 & 40.00 & 35.80 & 39.70 \\
\hline Copper (mg/l) & 0.07 & 0.04 & 0.07 & 0.03 & 0.04 & 0.03 \\
\hline Zinc (mg/l) & 0.15 & 0.11 & 0.14 & 0.13 & 0.11 & 0.14 \\
\hline Iron (mg/l) & 1.40 & 0.85 & 0.95 & 0.92 & 0.35 & 0.42 \\
\hline Lead (mg/l) & 0.002 & ND & 0.002 & 0.001 & ND & 0.002 \\
\hline Cadmium (mg/l) & 0.001 & 0.002 & 0.001 & 0.002 & ND & 0.001 \\
\hline & & ND: Not Detected & & & \\
\hline
\end{tabular}

Sewage and wastewater are common sources of nitrate. Nitrate is a final product of aerobic stabilization of nitrogenous compounds. It normally has a value below $20 \mathrm{mg} / \mathrm{l}$ in natural water. Nitrate concentrations obtained in this work for the untreated wastewater samples ranged from $1.90-4.00 \mathrm{mg} / \mathrm{l}$ with a mean value of $2.87 \pm 0.75 \mathrm{mg} / \mathrm{l}$ with the measured value for treated sample increasing to $8.27 \pm 1.22 \mathrm{mg} / \mathrm{l}$. Same trend was observed for nitrite concentration. The nitrate and nitrite results for both untreated and treated wastewater in this study are within the permissible standard limits i.e. $50 \mathrm{mg} / \mathrm{l}$ and $1 \mathrm{mg} / \mathrm{l}[12 ; 13]$. This is an indication that the plant might be inefficient in nitrate and nitrate treatment.

Table 2 Chemical characteristics of treated water samples.

\begin{tabular}{|l|l|l|l|l|l|l|}
\hline Physicochemical Parameters & Week 1 & Week 2 & Week 3 & Week 4 & Week 5 & Week 6 \\
\hline Nitrate (mg/l) & 9.50 & 8.50 & 6.90 & 10.00 & 8.00 & 6.70 \\
\hline Nitrite (mg/l) & 0.16 & 0.18 & 0.19 & 0.16 & 0.16 & 0.19 \\
\hline Phosphate (mg/l) & 2.10 & 1.70 & 1.30 & 2.30 & 1.10 & 1.00 \\
\hline Chloride (mg/l) & 33.80 & 22.80 & 27.90 & 35.90 & 23.90 & 26.90 \\
\hline Sulphate (mg/l) & 36.00 & 40.00 & 27.90 & 35.00 & 40.00 & 35.70 \\
\hline Copper (mg/l) & 0.01 & 0.01 & 0.03 & 0.01 & 0.02 & 0.02 \\
\hline Zinc (mg/l) & 0.02 & 0.02 & 0.02 & 0.01 & 0.10 & 0.12 \\
\hline Iron (mg/l) & 0.15 & 0.35 & 0.22 & 0.25 & 0.20 & 0.12 \\
\hline Lead (mg/l) & ND & ND & ND & ND & ND & ND \\
\hline Cadmium (mg/l) & ND & ND & ND & 0.001 & ND & ND \\
\hline & & ND: Not Detected & & & \\
\hline
\end{tabular}


Table 3 Statistical analysis of untreated and treated samples

\begin{tabular}{|l|l|l|l|l|}
\hline \multirow{2}{*}{$\begin{array}{l}\text { Physicochemical } \\
\text { Parameters }\end{array}$} & \multicolumn{2}{l}{ Untreated Wastewater } & \multicolumn{2}{l}{ Treated Wastewater } \\
\cline { 2 - 5 } & Mean & Range & Mean & Range \\
\hline Nitrate $(\mathrm{mg} / \mathrm{l})$ & $2.87 \pm 0.75$ & $1.90-4.00$ & $8.27 \pm 1.22$ & $6.70-10.00$ \\
\hline Nitrite $(\mathrm{mg} / \mathrm{l})$ & $0.13 \pm 0.03$ & $0.09-0.17$ & $0.17 \pm 0.01$ & $0.16-0.19$ \\
\hline Phosphate $(\mathrm{mg} / \mathrm{l})$ & $2.31 \pm 0.82$ & $0.97-3.00$ & $1.58 \pm 0.49$ & $1.00-2.30$ \\
\hline Chloride $(\mathrm{mg} / \mathrm{l})$ & $36.48 \pm 3.08$ & $30.50-40.00$ & $28.53 \pm 4.82$ & $22.80-35.90$ \\
\hline Sulphate $(\mathrm{mg} / \mathrm{l})$ & $39.95 \pm 3.43$ & $35.80-46.90$ & $35.77 \pm 4.05$ & $27.9-40.00$ \\
\hline Copper $(\mathrm{mg} / \mathrm{l})$ & $0.05 \pm 0.02$ & $0.03-0.07$ & $0.02 \pm 0.01$ & $0.01-0.03$ \\
\hline Zinc $(\mathrm{mg} / \mathrm{l})$ & $0.13 \pm 0.02$ & $0.11-0.15$ & $0.05 \pm 0.04$ & $0.01-0.12$ \\
\hline Iron $(\mathrm{mg} / \mathrm{l})$ & $0.82 \pm 0.35$ & $0.35-1.40$ & $0.22 \pm 0.07$ & $0.12-0.35$ \\
\hline Lead $(\mathrm{mg} / \mathrm{l})$ & $0.001 \pm 0.0009$ & ND - 0.002 & ND & ND \\
\hline Cadmium (mg/l) & $0.001 \pm 0.0007$ & $0.001-0.002$ & $0.0002 \pm 0.0004$ & $0.00-0.001$ \\
\hline & & ND: Not Detected & & \\
\hline
\end{tabular}

Phosphates exist in three forms of orthophosphates, polyphosphates and organic phosphates in nature. Different forms of phosphate are produced from a variety of sources. Phosphate concentrations obtained for untreated wastewater ranged from $0.97-3.00 \mathrm{mg} / \mathrm{l}$ with a mean value of $2.31 \pm 0.82 \mathrm{mg} / \mathrm{l}$, while that of the treated samples ranged from 1.00 - $2.30 \mathrm{mg} / \mathrm{l}$ with a mean value of $1.58 \pm 0.49 \mathrm{mg} / \mathrm{l}$. There were variations in the weekly results recorded for phosphate for the untreated wastewater. In aquatic ecosystems, because phosphorous is available in the low amount, it is usually the limiting nutrient for plant growth. This means that excessive amounts of phosphorous in a system can lead to an abundant supply of vegetation and cause low dissolved oxygen. Phosphate values results for both untreated and treated samples were below the permissible standard limits of $3.5 \mathrm{mg} / \mathrm{l}[12 ; 13]$.

Sulphate concentration obtained for untreated wastewater ranged between $35.80-46.90 \mathrm{mg} / \mathrm{l}$ with a mean value of $39.95 \pm 3.43 \mathrm{mg} / \mathrm{l}$, while that of the treated wastewater ranged between $27.90-40.00 \mathrm{mg} / \mathrm{l}$ with a mean value of $35.77 \pm 4.05 \mathrm{mg} / \mathrm{l}$. Sulphates in water is known to cause hard scales in boilers and heat exchangers. High amount of sulphates in wastewater may lead to problems due to the formation of hydrogen sulphide gas. Sulpahte is introduced into the river as a result of industrial and domestic activities [14]. In polluted wastewaters in which the dissolved oxygen is zero, sulphate can be easily reduced to sulphide causing noxious odour. Values of sulphate obtained in this work for both untreated and treated samples were below the permissible standard limits of NESREA, 2009 and WHO, 1996.

The heavy metals were at very low concentrations especial lead and cadmium. These metals are usually introduced to surface waters as waste from human activities. Some of the metals of concern to human and aquatic health are cadmium, lead, copper, cadmium etc. The content of $\mathrm{Fe}, \mathrm{Zn}, \mathrm{Cd}, \mathrm{Cu}$ and $\mathrm{Pb}$ recorded for the untreated water samples were $0.82 \pm$ $0.35,0.13 \pm 0.02,0.001 \pm 0.0007,0.05 \pm 0.02$ and $0.001 \pm 0.0009 \mathrm{mg} / \mathrm{l}$ respectively. After treated, there was decrease in all of these metal contents to $0.22 \pm 0.07,0.05 \pm 0.04,0.0002 \pm 0.0004,0.02 \pm 0.01$ and $0 \mathrm{mg} / \mathrm{l}$ respectively. Lead was not detected in the treated sample over the six weeks of analyses while cadmium was only detected in week four.

Iron concentration recorded for untreated wastewater was higher than the permissible effluent discharge limit of 0.3 and $0.5 \mathrm{mg} / \mathrm{l}$ by NESREA, 2009 and WHO, 1996. Acute lead poisoning in humans can cause severe dysfunction in some key organs and the central nervous system. Lead poisoning has been reported to have caused mental retardation in many children [15]. The lead concentration in this study was far below the NESREA and WHO prescribed limit for effluent discharge into river. Cadmium concentrations in this study also fell below the NESREA and WHO prescribed limit for effluent discharge into river. Zinc is essential to plant and animal physiology, high amount in water can cause problem of bitter, astringent taste and opalescent appearance [16]. Like many of the other metals, small amounts of zinc are essential for life. Copper content of untreated sample was between $0.03-0.07 \mathrm{mg} / \mathrm{l}$ with a mean value of $0.05 \pm 0.02$ $\mathrm{mg} / \mathrm{l}$ while that of the treated sample was between $0.01-0.03 \mathrm{mg} / \mathrm{l}$ with a mean value of $0.02 \pm 0.01 \mathrm{mg} / \mathrm{l}$. Copper is a toxic metals in the aquatic environment even in very low concentration. It is released into the environment primarily as a result of its use as a dormant spray in agriculture, as a fungicide in marine paints and from tailings from copper 
mines. In urban areas, copper is present in storm water runoff from roads due to tire wear. It is highly toxic to fish because it disrupts normal electrolyte (salt) balance.

\section{Conclusion}

The results for this study revealed that the chemical parameters of untreated wastewater samples analysed where higher than the treated wastewater samples except nitrate and nitrite, but were within WHO, 1996; NESREA, 2009 effluent discharge permissible limits. Importantly it could also be concluded that the sewage treatment plant is efficient and effective, but not efficient for the treatment of nitrate and nitrite. High levels of nitrites are toxic to humans and animals, especially infants.

\section{Compliance with ethical standards}

\section{Disclosure of conflict of interest}

We declare that we have no competing financial, professional or personal conflict of interests that might have influenced the performance or presentation of the work described in this manuscript.

\section{References}

[1] Kannel PR, Lee S, Kanel SR, Khan SP and Lee YS. (2007). Spatial-temporal variation and comparative assessment of water qualities of urban river system: a case study of the river Bagmati (Nepal). Environmental Monitoring and Assessment, 129(1-3), 433-459.

[2] Chang H. (2008). Spatial analysis of water quality trends in the Han River basin, South Korea. Water Research, 42(13), 3285-3304.

[3] Mvungi A, Hranova RK and Love D. (2003). Impact of home industries on water quality in a tributary of the Marimba River, Harare: implications for urban water management. Physics and Chemistry of the Earth, 28(2027), 1131-1137.

[4] Lin HY and Han WY. (2001). Water quality assessment and analysis before and after the decade of the dry period in Lingdingyang Estuary of the Pearl River Mouth. Journal of Marine Environmental Science, 20, 28-31.

[5] Ganoulis J. (2009). Risk Analysis of Water Pollution, second edition. WILEY-VCH Verlag GmbH \& Co. KGaA; Weinheim, Germany, 1-311.

[6] WHO and UNICEF Joint press release. (2017). 2.1 Billion People Lack Safe Drinking Water at Home, More Than Twice as Many Lacks Safe Sanitation.

[7] Ranade VV and Bhandari VM. (2014). Industrial Wastewater Treatment, Recycling, and Reuse: An Overview. Chapter 1. Chemical Engineering and Process Development Division. CSIR-National Chemical Laboratory, Pune, India, 1-80.

[8] Kahmeyer M, Miller C, Neppel K, Ronnebaum C, Webber J and Zinke B. (2001). Waste Characterization Study for KSU Recycling.

[9] Arslan A and Ayberk S. (2003). Characterisation and biological treatability of Izmit industrial and domestic wastewater treatment plant wastewaters. Water SA, 29(4), 451-456.

[10] Yadav RK, Goyal B, Sharma RK, Dubey SK and Minhas PS. (2002). Post-irrigation impact of domestic sewage effluent on composition of soils, crops and ground water-a case study. Environ. Int., 28, 481-486.

[11] Dixon A, Butler D and Fewkes A. (1999). Water saving potential of domestic water reuses systems using greywater and rainwater in combination. Water Sci. Technol., 39, 25-32.

[12] NESREA. (2009). National Environmental Standards and Regulation Enforcement Agency (NESREA) Regulations. Volume 96, Number 65, The Federal Government Printer, Abuja, Nigeria.

[13] WHO. (1996). Guideline for Drinking Water Quality. 2nd Edition, Volume 2, Health Criteria and Other Supporting International Programme on Chemical Safety, World Health Organization, Geneva. 
[14] Salaudeen AO. (2016). Physicochemical Analysis of Water from Asa River, Ilorin, Nigeria Water samples were taken at four different locations along the course of Asa river within Ilorin Ilorin, Kwara state. Imperial Journal of Interdisciplinary Research, 2(3), 2454-1362.

[15] Salaudeen AO, Adeloju E and Abdulkareem A. (2016). Concentrations of Heavy Metals in Water, Sediment and Fish Parts from Asa River, Ilorin, Kwara State. Imperial Journal of Interdisciplinary Research, 2(4), 2454-1362.

[16] APHA. (1980). Standard Methods for the Examination of Water and Wastewater. American Public Health Association.

\section{How to cite this article}

Chibueze CO and Salaudeen AO. (2020). Heavy metals and anions content of treated and untreated waste water samples from Wupa sewage treatment plant Abuja. World Journal of Advanced Research and Reviews, 6(1), 139-145. 